\title{
C. G. JUNG'S ENCOUNTER WITH HIS FRENCH READERS. THE PARIS LECTURE (MAY 1934)
}

FLORENT SERINA

$P H A N \hat{E S} \cdot \operatorname{VOLUME} 1 \cdot 2018 \cdot$ PP. 111-137

https://doi.org/10.32724/phanes.2018.Serina 


\begin{abstract}
This article recounts a little-known episode in C. G. Jung's life and in the history of analytical psychology: Jung's visit to Paris in the spring of 1934 at the invitation of the Paris Analytical Psychology Club (named 'Le Gros Caillou'), a stay marked by a lecture on the 'hypothesis of the collective unconscious' held in a private setting and preceded by an evening spent in Daniel Halévy's literary salon with some readers and critics.
\end{abstract}

\title{
KEYWORDS
}

collective unconscious; France; Julien Green; Daniel Halévy; Lucien Lévy-Bruhl; Ernest Seillière. 


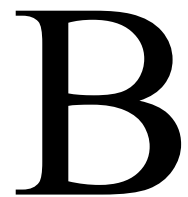
ased on published evidence, the question of whether or not Carl Gustav Jung gave a lecture in Paris remains rather confused. The editors of the Collected Works do not mention such an event, while Jung's recollections as recorded in Memories, Dreams, Reflections state that he presented 'The Structure of the unconscious' as a lecture in Paris in the course of 1916 (Jung/Jaffé [1962]: 297). In fact, contrary to words that were attributed to him, Jung never presented this work as a lecture in the French capital. The assertion that he did is not supported by the Protocols of Memories, Dreams, Reflections, in which Jung makes no mention of it. In addition, France was at war with Germany at that time, and therefore scientific activities and exchanges were relatively limited. 'The structure of the unconscious' was the subject of a lecture at the Zurich Club, prior to being published in a French translation in the journal of Théodore Flournoy and Édouard Claparède, the Archives de psychologie, edited in Geneva. Since Jung regularly visited Théodore Flournoy's home in Florissant during the years following his break with Vienna - a gathering place where members of the Geneva school and of the Zurich school met-it is possible that he presented all or a part of this work there, in a private setting.

On consulting the parts of his correspondence selected by Aniela Jaffé and Gerhard Adler, one can see that Jung was invited in 1933 to give a lecture at the Sorbonne but refused. Indeed, he wrote to his Basel student Elisabeth von Sury (1878-1956), who had obviously forwarded him the invitation:

It would look too much like making propaganda for my own cause. I would regard such a procedure as not only unintelligent but misleading as well. I have always acted on the principle that if people have the need to hear me they could also invite me to speak. I would therefore prefer to wait and see whether something will stir spontaneously in Paris or not. I have found over and over again that it is not worthwhile speaking to an unprepared public. My whole psychology is such that it can be accepted only by someone who is ready for it. It is too little in accord with the conscious expectations of the time to be grafted on to something known. So let us wait and leave it to the intellectual development of France whether or not to adopt a positive attitude to this kind of psychology (Jung to Elisabeth von Sury, 14 November 1933, in Adler, Jaffé 1973: 130-131).

As a matter of fact, the invitation did not come directly from the 
Sorbonne, but was most certainly issued by the Groupe d'études philosophiques et scientifiques pour l'examen des idées nouvelles (Philosophical and Scientific Studies Group for the examination of new ideas). This group was founded in 1922 and led thereafter by René Allendy (1889-1942), physician and psychoanalyst, and his wife, the art critic Yvonne Allendy-Nel-Dumouchel (1890-1935), known by her pen name Jacques Poisson. This group, interested in avant-garde currents, used to welcome artists and intellectuals as speakers. In psychology, for example, Otto Rank, Alphonse Maeder and Alfred Adler each gave a lecture there in the mid-1920s. Jung probably did not know exactly who had issued the invitation, since René Allendy was one of those French psychoanalysts most receptive to his theories, having contributed by his essays to their popularisation ${ }^{1}$. Jung was probably more willing to consolidate the base of his disciples already won over to his cause, rather than fight with academics, fearing that they would judge his assumptions too risky.

Elisabeth von Sury's response was not kept in his archives. However, it appears that she managed to convince him to come to Paris to give a private lecture on 30 May 1934, especially for the members of the psychological club she had founded a few years prior to that date. Before recounting the history of this little-known episode in Jung's life and in the history of analytical psychology, I would like to focus on the events that preceded it the day before, more specifically the evening, that Jung spent in another socially convivial place, the salon of the historian and essayist Daniel Halévy.

\section{IN DANIEL HALÉVY'S SALON}

Daniel Halévy (1872-1962) was the son of Ludovic Halévy, of Jewish origin, and Louise Breguet, who was descended from a long line of

\footnotetext{
${ }^{1}$ C. G. Jung and René Allendy met several times the following years. Their first meeting took place in October 1937 during the $9^{\text {th }}$ International Medical Congress for Psychotherapy in Copenhagen, where the French psychoanalyst was invited to lecture (Frémont 1994: 116-117). They also met at the annual meeting of the Society for Nature Research, Basel, 7 September 1941, organised by the Swiss Society for the History of Medicine and the Natural Sciences to commemorate the 400th anniversary of Paracelsus' death. In 1945, receiving a book written in tribute to Allendy, who had died prematurely three years earlier, Jung thanked his publisher, saying he was delighted to have 'this memory of a remarkable man' (Jung to Jean Desplanque, 18 June 1945, ETH Zurich). As for whether he was inspired by his work in alchemy, there is no reason to think so. Just as he described in Psychologie and Alchemy, his study on La symbolique des nombres (The Symbolism of Numbers) as a 'very valuable account' (1944-1952, CW 12: §313).
} 
Protestant watchmakers. He made a name for himself by publishing the first French translations of Friedrich Nietzsche's work. He became a passionate follower of Nietzsche at an early age, and subsequently authored a biography that became a standard work. He was close to Marcel Proust, with whom he became friends while he was a high school student, and aligned himself with Alfred Dreyfus, but then made a left turn, approaching Georges Sorel, Charles Péguy, and Paul Desjardins. Director of the 'Cahiers verts' at Grasset (editor of the famous 'four Ms', François Mauriac, André Maurois, Henri de Montherlant and Paul Morand), host of a very popular salon, critic and essayist, Halévy had real 'literary power' in the Paris of the twenties (Laurent 2001).

The historian's relationship with psychoanalysis and theories of the unconscious cannot easily be described. Halévy said he was an admirer of Paul Bourget, one of the very first French writers to pay public tribute to Sigmund Freud-his Essais de psychologie contemporaine (Essays of contemporary psychology) having been 'one of the solid readings of [his] youth' (Halévy 1920, 175). But unlike many men of letters of his generation, Halévy had no particular interest in Freud. Being a regular contributor to the Revue de Genève, he had undoubtedly discovered Freud as early as 1920, as well as the published translation of his Worcester lectures $^{2}$. However, he devoted only these few lines to him in 1932:

Freud, Einstein, these are the new masters, the craftsmen today of the abandonment [of nature]. Freud steals our souls from us: what we knew, what we thought we knew about them, was, it seems, only the quick and carefully simplified sight of a distant swell of elementary instincts which is the substance, which is all we are, and which in no way resembles the human idol that we had set up (Halévy 1932a: 53).

As for Jung, Daniel Halévy seems to have discovered the man as well as his works during a gathering on the perimeter of the meeting of the Europäische Kulturbund (European Cultural League) in Zurich on 1 June 1932. He praised him in an article in Les Nouvelles littéraires:

At the forefront of these hosts who welcomed us, I will name the eminent philosopher and psychiatrist C. G. Jung, whom we know so little about in France. He is a prince in his city,

2 Nevertheless, Lou Andreas-Salomé (1861-1937), Friedrich Nietzsche's muse, and Freud's friend and disciple, visited his salon in the 1920's. 
the affable and friendly prince of an entirely republican city. Let us admit that we are often slow in our readings. Belatedly, we read Freud, and today we barely know (or we do not know) that Jung, his continuator and in no way his disciple, breaking up the narrow formulas in which the master imprisons himself, has succeeded in making psychoanalysis an admirable instrument for the knowledge of man and his history, from the most distant to the closest (Halévy 1932a: 2) .

The following year, Daniel Halévy sketched his portrait in slightly different terms in a chapter of his new essay, Courrier d'Europe:

The chairman of this evening is Jung, the eminent Swiss psychiatrist and philosopher, whom we do not know well enough in France. Belatedly, we read Freud, we keep to the penetrating but narrow formulas of the Viennese fanatic, and we do not know Jung, this master connoisseur of man, of his history, this great explorer of his ordeals, of his aspirations. Here he is, a perennial and cheerful sexagenarian, and who has this delicious, good-oldboy affability of the bourgeois of Basel, prince in his city, sweet naturedprinceofacompletelyrepublicancity(Halévy 1932b:237).

Daniel Halévy seems to have emerged as an admirer of the man, regretting that he did not have the time and freedom to translate his work. His article ends with these lines: 'I would like to have six or eight months entirely free, to devote them to the study of this great spirit, to translate his work, to make it accessible to our public. This is the task of a younger person, I trust that he will be found' (Halévy 1934: 2). If this had been the case, Nietzsche and Jung would have had the same French translator.

A few days before his departure for Paris, Jung received an invitation from Halévy, who was personally informed of his arrival, inviting him to join him and his guests:

A card tells me that on the 30th, you are giving a lecture in Paris. I found out that your editors did not know it, that my fellows who read and learn from your books also did not know it. I warned them, they can hear you. But I would really regret, I would find it unfortunate that, passing through Paris, the opportunity is not seized to establish a contact between you and your best readers, between you and a few good minds from here. 
Would you like to come to my place, Place Dauphine 26, on May 31, June 1 or any other day? I wouldn't burden you with futile assistance, but I would certainly bring together about ten attentive people (Halévy to Jung, 23 May 1934, ETH Zurich).

Jung wrote to him to thank him for his message, saying that he did not intend to stay long, but that he agreed to join his salon the day before the lecture, and said that he would be 'enchanté to meet his Parisian readers' (Jung to Halévy, 24 May 1934, ETH Zurich).

In addition to journals, literary salons have long counted as high places of sociability and cultural exchange in France. Although the phenomenon was probably not as important as in the previous century, there were still a few in Paris in the Années folles, including that of Halévy, which was still very influential at the time (Laurent 2001: 315-320). Halévy's Second Empire salon was located in his vast apartment, decorated by Degas' paintings, on the Ile de la Cité, just a few steps from the Pont Neuf. It was known for bringing together men of letters from different generations and sensibilities. A journalist described the place at the beginning of the decade:

We find representatives of all literary horizons united in good intelligence, under the liberal and penetrating eye of the master of the house. In front of the beautiful waters of the Seine that can be seen from the windows of the living room, Mr Guéhenno and Mr Gabriel Marcel meet each other without acrimony and the most violent polemicists approach each other with a smile (Sygne, 1932).

According to one of his regular guests, 'a fine light, filtered by the foliage of the large trees of the quay, gave rise to a soft and scarcely audible ambiance, favourable to attentiveness and polite discussion' (Mazauric 1972). However, some of his friends like Julien Benda, Romain Rolland, Albert Thibaudier, Jean Guéhenno, or André Chamson were beginning to keep their distance. Formerly known as a left winger, Halévy was ostentatiously drifting towards Maurrassism. His public support for the violent demonstration of 6 February 1934 organised by extreme rightwing leagues soon earned him, in the eyes of some, the reputation of an untrustworthy reactionary (Pellissier 2000; Jenkin \& Millington 2015). This was confirmed by the publication in the spring of the anti-parliamentary lampoon, La République des comités (The Republic of Committees). It is unfortunately impossible to identify all the guests of this 
reception. But the presence of a few personalities on the evening of Jung's arrival is nonetheless perfectly proven. Among them was the philosopher and sociologist Lucien Lévy-Bruhl (1857-1939). While this was probably their first meeting, his work was well known to Jung. He had even borrowed several notions from the author of La Mentalité primitive, including that of 'participation mystique'. Also present was the writer and poet Pierre-Jean Jouve (1887-1976) who was a regular at the salon. ${ }^{3}$ He was probably accompanied by his wife, the Genevan psychiatrist Blanche Reverchon (1879-1974), member of the Société Psychanalytique de Paris, and translator of Freud's Drei Abhandlungen zur Sexualtheorie. (Although the salon was almost exclusively male, it is said that while wives might be invited, they were nonetheless expected to remain silent). One of Jung's most virulent critics of the inter-war period, the philosopher and essayist baron Ernest Seillière (1866-1955), was also present.

For the rest, one is reduced to speculation. One could imagine a few personalities close to the salonnier whose present or future interest in Jung's work is acknowledged: Pierre Drieu La Rochelle, ${ }^{4}$ Edmond Jaloux, who wrote a foreword to Jung's anthology Essais de psychologie analytique (1931), or the philosopher Gabriel Marcel. ${ }^{5}$ One might also presume the presence of Jean Giraudoux, Louis Guilloux, André Suarès, André Siegfried, Fernand Gregh, Jacques-Émile Blanche, Marcel Guérin, André Spire, Robert de Traz, François Mauriac, or Henry de Montherlant, if one were to mention the most regular visitors at that time.

Jung himself offered a lively glimpse into this 'nice evening in Paris' during his lectures in London at the Tavistock Clinic in the autumn of 1935, an account which was to his advantage. The Zurich psychologist told his audience that 'very cultivated men had invited' him, and that they had had 'a pleasant conversation'. Asked about national differences, he said he had not hesitated to 'put [his] foot in it', explaining what he thought was psychologically the most clear-cut distinction between the French and the Germans:

What you value is la clarté latine, la clarté de l'esprit latin.

\footnotetext{
3 Pierre-Jean Jouve reminds Jung of his presence that evening in a letter sent in 1945 (Jouve to Jung, 8 June 1945, ETH Zurich).

4 Pierre Drieu la Rochelle (1893-1945) had read Jung through the Argentine publisher Victoria Ocampo with whom he had a love affair (Ocampo 2007: 131).

5 Gabriel Marcel (1889-1973) said in an interview with Maurice de Gandillac: 'Jung interests me much more than Freud, and I think he goes much further' (Centre culturel international de Cerisy-la-Salle 1976: 225).
} 
That is because your thinking is inferior. The Latin thinker is inferior in comparison to the German thinker." They cocked their ears, and I said: "But your feeling is unsurpassable, it is absolutely differentiated." They said: "How is that?" I replied: "Go to a café or a vaudeville [...] and you will notice a very peculiar phenomenon. There are any number of very grotesque and cynical things and then suddenly something sentimental happens. [...] For you, the salt and the sugar have to go together. But a German can stand a whole evening of sugar only. The Frenchman must have some salt in it. You meet a man and say: Enchanté de faire votre connaissance. You are not enchanté de faire sa connaissance at all; you are really feeling: "Oh go to the devil." But you are not disturbed, nor is he. But do not say to a German: Enchanté de faire votre connaissance, because he will believe it (Jung 1935, CW 18: §95).

The statement that the French mind and the French language are characterised by their clarity is far from original (Swiggers 1987). In the latter part of the eighteenth century, Antoine de Rivarol wrote in his Discours sur l'universalité de la langue française (1784): 'what is not clear, is not French' ('ce qui n'est pas clair n'est pas français'). Great Germanic writers such as Goethe, Nietzsche and many others also convey admiration for this supposed clarity. In 1928, the Baltic German philosopher Hermann von Keyserling (1880-1946) described the French mind in Das Spektrum Europas (The Spectrum of Europe) as follows:

while the rest of the world increasingly stresses the irrational powers of the unconscious, France lays the stress, more than ever before, on intelligibility. From this point of view we are at last able to offer a final evaluation of the significance of the French limitation of mind. [...] France can play the leader only in a time of fulfilment, when it is a question of imparting final perfection to an accepted world. The blazing of new paths is not for this race (Keyserling 1928: 61-62).

Jung never gave a complete picture of the psychology of the French people, nor did he for that of other nations. Nevertheless he appears to be in agreement with Keyserling's reflections. In a review of his essay, he asserts:

Whatever may be perceived on the broad surface, Keyserling 
sees brilliantly $[\ldots]$. With regard to France, he has hit the nail on its head (which is Paris), but the Frenchman buried in the countryside remains invisible, essential though he is to the picture (Jung 1928, CW 10: §908).

Nevertheless Jung goes beyond this topos, or rather myth, in linking the supposed French clarity to his theory of psychological types. Thus, after having classified different psychological types and functions on an individual scale in Psychologischen Typen (1921), Jung tried to apply this methodology to the area of nationalities and peoples, or, in other words, to collective psychology (Pietikäinen 1998). And in this manner, France and Germany would oppose each other by their 'rational function', thus giving a psychological explanation for the two wars that had opposed the Western Europe's 'hereditary enemies'.

Probably expecting Daniel Halévy to invite only an audience of admirers or benevolent readers, Jung may have been surprised to have to face a small group of detractors, determined to cross swords with him. Indeed, it is also known that Jung confided to an American friend, who was also undergoing analysis with him, that his conception of a collective unconscious was fiercely debated by a small group of guests. Some of them expressed their opposition, with the notable exception of Lucien LévyBruhl and Daniel Halévy, both of whom, as Jung pointed out in Cabot's account, were Jews. However, it was said that Halévy was habitually self-effacing, ensuring that everyone had a chance to speak, turning the discussion to other topics from time to time, and most often trying to show his guests off to their advantage. But the others would have protested, with Baron Ernest Seillière first and foremost: 'Mais cher Monsieur, c'est de la religion' ('But dear Sir, this is religion') (Cabot 2001: 345). ${ }^{6}$

Actually Ernest Seillière did not wait to meet him personally in

\footnotetext{
${ }^{6}$ Catharine Rush Cabot writes: 'He then told me how once he was invited to a meeting of famous French scientists. At the meeting there was Halévy (a famous biographer of Nietzsche) and Lévy-Bruhl. He said that they inquired about "my concept of the Collective Unconscious. Another man present, the Baron de Ségur, said that my concept of the Collective Unconscious was a mystical conception. I explained to the scientists that it produces the myths of the world, a part of the human mind which functions everywhere. No one understood except Halévy and Lévy-Bruhl, who were Jews. The others said, 'Mais cher Monsieur, c'est de la religion'. I replied, 'Do you call that "religion" when I tell you that I am a professor of the research of myths?' But they couldn't understand, and then I saw that the corresponding thing to the concept of the Collective Unconscious was for a Frenchman the Church"'. Cabot obviously confuses the so-called 'Baron de Ségur' with Baron Ernest Seillière. Jung may also remember his book Nietzsches Waffenbruder, Erwin Rohde (1911), of which he had a copy.
} 
Halévy's salon to debate, or rather, discredit his theory of the collective unconscious. If he considered this theory 'infinitely more acceptable... than Freud's uniformly sexual psychology', his essay on Le Néoromantisme en Allemagne (Neo-Romanticism in Germany) (1931), denounced the supposed dangers of a 'mystical and imperialistic pangermanism'. It sought to unmask what he considered to be Jung's disguised metaphysics as leading to the deification of the Hartmanian and Freudian concept of the unconscious (Seillière 1931:60). The Parisian aristocrat seems to have taken advantage of the opportunity to offer the guest a copyunsigned - that Jung kept intact and unread in his library. Seillière would take advantage of the publication of the first French translation of Die Beziehungen zwischen dem Ich und dem Unbewussten to tell his readers that:

Mr Jung does not readily accept being called a mystic because he bases his theoretical views on his vast experience as an empirical psychologist. It seems to me, however, that when he synthesizes them, he nevertheless moves toward the deification of the Collective Unconscious in order to form an alliance with it. In my view, this is the very definition of mysticism and the most fruitful of all in drawing enlightening conclusions (Seillière 1938: 3).

Considering that an in-depth discussion with Halévy's guests would be futile, Jung came to the conclusion that what would best correspond to the collective unconscious for a Frenchman could only be the Church, and that their Catholicism was an obstacle to the discussion. He asserts during his seminar on Nietzsche's Zarathustra a couple of weeks later:

I had an opportunity lately to talk to some French people who are Catholic to the marrow of their bones, and for them that whole sphere of psychological or religious experience, which is so conspicuous in primitives for instance, simply does not exist. It does not exist, because it is in the church. But then you would assume that they believed in their Catholicism. Not at all! They are Catholic with an a, a-Catholics, but they are in the church. [...] They organise themselves most probably in a free-thinking society or a society for atheist propaganda. But their whole psychology is still in the Catholic Church in its positive or negative form (Jung 1989:96).

Irritated by their attitude, he ends up with an unflattering 
comparison of his interlocutors with the penguins of the Anatole France's novel, L'île des pingouins (Penguins Island): ${ }^{7}$

To say anything about Nietzsche, or to mention analytical psychology to such people, is perfectly preposterous-you could talk to the penguins just as well. I felt like St. Malo, only I was not blind and deaf: I saw that they were penguins. They were only the conscious half of man - the unconscious didn't exist - and the conscious half was the walls of the church (Jung 1989: 96).

Obviously, this evening at Halévy's parlour did little to change his opinion of the French about whom he had said almost ten years earlier during another seminar:

Their rationalism is blocking them at every point. They have an exact view about everything and know what it is to the last dot. They exhaust themselves in that fight. Because of this knowing how everything works, they are inclined to depreciate the immediate facts of the soul, and to assume that everything is the result of an old civilisation (Jung 2011: 167).

One is also reminded of these remarks reported by Jung's French translator and disciple, Roland Cahen, in his preface to L'Homme à la découverte de son âme (1944) (Man in Search of his Soul), which seem to directly echo what transpired during this Parisian evening:

In his opinion, the French, as far as concerns the mind, are little open to empirical viewpoints and the demands of phenomenology. They are either under the influence of the Church, which gives an answer to questions that seem lawful to them and hinders others, or they leave the Church and try to attack her from the outside. But, in either case, the Church occupies a place of honour for the French spirit, which tires and exhausts itself by wondering whether the Church's truth is valid or not. This central concern

\footnotetext{
7 James L. Jarrett notes that Jung confuses St. Malo with another figure of the novel, St. Muel (Jung 1989:96 n. 8). Besides a copy of L'île des pingouins (1908), Jung had other books by Anatole France (1844-1924) that he appreciated a lot (as did Freud and Ferenczi), frequently quoting regularly his saying: 'Les savants ne sont pas curieux'. Jung possessed indeed Le jardin d'Épicure (1895, 1908 edition), L'Orme du mail (1897, 1919 edition), La rôtisserie de la reine Pédauque (1893, 1909 edition) and Sur la pierre blanche (1905, 1906 edition), all in French.
} 
leaves little room, little fresh receptivity to new concepts that might upset the traditional debate (Cahen 1944: VI-VII).

A few weeks after this evening, Daniel Halévy published a portrait of 'the illustrious master of Zurich', whom he says he was 'happy' to receive and hear, considering that he deserved 'our attention much more than we have so far given it to him'. Halévy presents Jung as a 'lively, talkative, inexhaustible storyteller', with the look of an 'athletic fiftyyear old', and most importantly as the one who knew how to 'unblock the impasse' in which Sigmund Freud had taken psychoanalysis:

Freud discerns only the repressed elements of individual life, Jung sees life as immense. Imagine a night landscape through which passes a beam of light, stopping here and there; this is our soul, the part that we know is contained in the thin, moving, luminous space. Dark or bright, it lives completely like the landscape with its flora, fauna, and a past from which nothing dies: it contains energies, richness that we can barely see. This is Jung's main idea, and the origin of his research (Halévy 1934: 3).

Receiving a copy of the journal, Jung wrote to Halévy in August thanking him for his 'kind letter'-which has not been preservedand for his article, which had 'greatly interested him'. And in return, he sent him a collection of his articles, probably Wirklichkeit der Seele, which had just come off the press (Jung to Halévy, 17 August 1934, ETH Zurich). Their exchanges were probably not continued.

As for Lucien Lévy-Bruhl, Jung had the opportunity to speak with him again when he was invited by the Psychological Club to give a lecture in Zurich on 9 February 1935 on 'L'expérience mystique des primitifs' ('The mystical experience of the primitives') (Lévy-Bruhl 1936-1937; 1938). ${ }^{8}$ Shortly after his return to Paris, the sociologist sent him a copy of his essay on La Mythologie primitive (where he uses

\footnotetext{
8 Lucien Lévy-Bruhl's diary gives some details about his stay in Zurich. On 8 February 1935, the day of his arrival, he had lunch with Toni Wolff, Olga FröbeKapteyn, Markus Fierz and Linda Fierz-David, followed by a lecture at the Naturforschende Gesellschaft in the evening. The next day, he had lunch in Küsnacht with the Jung, Marie-Jeanne Schmid, the Fierz and Toni Wolff, and then gave a lecture at the Club. On the 10th, he met Olga Fröbe-Kapteyn again (who invited him to Ascona), and had lunch at the Zurich main station with Toni Wolff (who obviously asked him to contribute to Jung's Festschrift), before taking a train back to Paris (LévyBruhl 1935b). On their meeting in Küsnacht, see also de Angulo 1977: 170-171.
} 
the term of 'archetype' once, but in a rather vague sense), 'in memory of his very kind welcome'. ${ }^{9}$ Jung only merely confirmed receipt (Jung to Lévy-Bruhl, 21 February 1935, IMEC), but obviously read this book carefully; his copy of that volume containing many pencil marks. A few weeks later, in a letter to Jolande Jacobi, he described his guest as a 'delightful relic', praising the material of his books for their 'priceless value', saying also he regretted that he failed to bring anything new to the occasion of his visit to Zurich. (Jung to Jacobi, 12 March 1935, ETH Zurich). Jung finally expressed his 'very sincere gratitude' after receiving the Festschrift that the Zurich Club offered him for his $60^{\text {th }}$ birthday (Jung to Lévy-Bruhl, 31 July 1935, ETH Zurich) for which Lévy-Bruhl wrote a special article on the initiation of medicine men (Lévy-Bruhl 1935a).

We also know that Olga Fröbe-Kapteyn, the founder of Eranos, offered Lévy-Bruhl to come to Ascona in August 1935, but he told her that his chances of being unoccupied at that time 'were very small'. He confirmed his refusal a few weeks later in a letter, probably addressed to Baron Eduard von der Heydt, saying also that he read the first two volumes of the Eranos-Jahrbücher, stating: 'The 1934 one, which I recently received and which I have just read, interested me even more than the first one; it throws a lot of light on questions of capital importance' (Lévy-Bruhl to Eduard von der Heydt, 26 April 1935, Fondazione Eranos). Fröbe invited him a second time the following year, and obtained a personal interview at his Parisian home (Olga Fröbe-Kapteyn to Lévy-Bruhl, 28 October 1935, IMEC). Although he still refused to come, Lucien Lévy-Bruhl seems to have accepted to play an intermediary role between Eranos and the French academic world to make the work of the circle known (Fröbe-Kapteyn 1942: 3). The 1936 Tagung was indeed marked for the first time by the presence of French scholars (Paul Masson-Oursel, Henri-Charles Puech and Boris Vysheslawzeff), thus compensating for the enforced absence of several German speakers, prevented from attending by the Nazi government ${ }^{10}$.

\footnotetext{
9 Before going to Zurich, Lucien Lévy-Bruhl had passed through Vienna where he conversed with Sigmund Freud. The latter will say about the French scholar: 'He's a real savant, especially by comparison with me.' Lévy-Bruhl also sent him a copy of his Mythologie primitive for which Freud sent him a thank-you note (Freud to LévyBruhl, 20 February 1935, IMEC).

${ }^{10}$ Upon hearing the news, Jung expressed his disappointment to his German friend Gustav Richard Heyer (1890-1967), complaining that they shall have to speak French or English during the Tagung. He then concluded with this Latin formula: 'O quam mirabilis sunt viae vestrae!' (Oh, how strange are your ways) (Jung to Gustav Richard Heyer, 1 August 1936, ETH Zurich).
} 


\section{'THE HYPOTHESIS OF COLLECTIVE UNCONSCIOUS'}

Since the founding of the Zurich Club, Jung had given private lectures or seminars to his followers in various groups or associations on a regular basis, bringing together some of his collaborators and patients. Wishing to test his latest theories and studies with an audience familiar with his thoughts, he often rehearsed his ideas in front of members of the Zurich Club, who were privileged to preview his upcoming lectures and his work in progress. Jung also accepted to speak more sporadically at the invitation of different groups of admirers living abroad, a sure way of building a lasting relationship with his disciples. Thus, after England, where he held several seminars in the 1920s, and Berlin, where he gave a seminar two years after the foundation of the C. G. Jung-Gesellschaft, he went to Paris, not to give a seminar but a single lecture. The reason for this is that the French Club remained very discreet and secret in comparison with the others, and none of its members were doctors or psychiatrists but only amateurs, with the exception of Elisabeth von Sury, who was a lay-analyst.

The initiative of this Parisian association came from Elisabeth von Sury, a founding member of the Zurich Club. Unfortunately, not much is known about her. The Club published in its yearbook an obituary, paying tribute to her 'benevolent, noble and gracious nature', her 'warmth', her sense of compassion, her sense of humour and her 'exemplary commitment' (Psychologische Club Zürich 1956-57: 12). Nurse by training, analysed by C. G. Jung, Elisabeth von Sury first practised analysis in Riehen, in the canton of Basel. She was the aunt of Jung's personal secretary MarieJeanne Schmid, herself the daughter of Marthe Guisan and Hans Schmid, of whom she was also the former pupil and close friend. For unknown reasons, Elisabeth von Sury moved to Paris at the beginning of the twenties, becoming the very first Jungian analyst in France. She was perhaps even the very first psychoanalyst to be installed in the country. ${ }^{11}$ Over the years, a patient base was formed, probably by word of mouth, and essentially from the Protestant bourgeoisie living nearby. In the autumn of 1926, she encouraged her analysands to meet at her home so that they could jointly study Jungian theories on the model of the Zurich Psychological Club. Hence they formed one of the first French associations grouping analysts or patients in psychotherapy in order to collectively deepen the study of a psychological doctrine. The French Club, named 'Le Gros Caillou' in

11 Perhaps Elisabeth von Sury, like Eugenie Sokolnicka (1884-1934) with Freud, received in 1921 a kind of mandate from C. G. Jung to thwart the development of the Viennese school in Paris. 
reference to the neighbourhood in Paris where most of its members lived, thus appears as the first Jungian association in France, and, after Zurich and London, as the third psychological club in Europe and in the world.

A few weeks after the premature death of Hans Schmid-Guisan, who had sponsored the Paris Club in its early years, Jung and his wife went to the French capital for their first visit in July 1932 - a little over a month after going to the Alsatian Pastoral Conference in Strasbourg (Jung 1932, CW 11: §§ 488-538). However, only his wife Emma Jung gave a lecture - presumably in a strictly private setting — on the theme of the animus, which was later followed by several working sessions in the Club. ${ }^{12}$ On his return home, C. G. Jung wrote to their president, Jean Bruneton, that he had 'an excellent memory of the evening at the Gros Caillou and especially of the dinner with [his] family', whom he said he had 'been very happy to meet' (Jung to Bruneton, 18 July 1932, ETH Zurich). A good part of this Protestant religious family probably attended the dinner. In addition to Jean Bruneton (1872-1952), an engineer with a passion for analytical psychology, and his wife Cécile (1879-1940), Jung shared dinner with Jean's brother, Gaston Bruneton (1882-1961) — known by historians for his role in the Vichy regime and his personal relationship with maréchal Philippe Pétain in the forties (Arnaud 2000) - , his wife, Jeanne (1888-1973), and their sister Marie Bruneton (1877-1962), a social worker actively involved in the Union Chrétienne de Jeunes Filles, the French branch of the Young Women Christian Association. Most of them had been patients of Hans Schmid-Guisan, and following his death, Jung had given a few sessions of analysis to Jeanne and Marie Bruneton. ${ }^{13}$

His lecture, which took place in a private setting, was held on 30 May 1934. That evening, the audience was made up of at least forty people, according to Jean Bruneton's estimate (Bruneton to Jung, 25 December 1933, ETH Zurich). There were perhaps even more, since some guests may $h$ ave arrived at the last minute thanks to Daniel Halévy. In addition to the members of the Gros Caillou, one can suppose that Jung's daughter, Gret Jung-Baumann and her husband Fritz Baumann might have

\footnotetext{
12 'On the Nature of the Animus' was read at the Psychological Club of Zurich 21 November 1931 and was first published, in a slightly expanded form, in Wirklichkeit der Seele (1934). See E. Jung 2004.

13 See their correspondence kept at the ETH Zurich.
} 
been there. They lived near Paris at that time, and contributed from time to time to the life of the Club. ${ }^{14}$ It is known that Jung's disciple Jolande Jacobi was present; Jung asked Jean Bruneton to send her an invitation. His translator Yves Le Lay may have made a special trip, as well as his friend and former patient Emil Medtner, who supervised the edition of his French translations. There were undoubtedly several personalities whom he had met the day before: Daniel Halévy, Lucien Lévy-Bruhl, Ernest Seillière, and the couple Jouve-Reverchon. One also knows of the presence of Édouard Pichon, another member of the Société Psychanalytique de Paris and Pierre Janet's son-in-law, who was then trying to work out of a synthesis between Janet's theories and psychoanalysis (Pichon 1934: 63). ${ }^{15}$ And it is quite probable that his young friend and follower, the future leader of the French psychoanalytic movement, Jacques-Marie Lacan, was also there. ${ }^{16}$ One can equally assume the presence of Fernand Aubier, who

14 In 1926, Fritz Baumann obtained a job in France to represent the interests of Georg Fischer, a Swiss industrial company, selling tube components (or similar) and settled in the Paris region, in Bellevue en Seine-et-Oise (now Meudon in the Hauts-de-Seine). With their two children Dieter, and René (who later translated several books under the direction of Roland Cahen Présent et avenir, and Un mythe moderne). A third one, Wolfgang, will be born on French soil. The family lived in France for twelve years until World War II broke out.

15 Édouard Pichon (1890-1940) wrote: 'In a very interesting private lecture given by Mr. Jung, which I had the honour of attending, this author, after quite rightly protesting that sexuality did not represent the entire content of the unconscious, came to bring out the role of the "male principle" and the "female principle" in the psychic productions (mandalas) that he presented to his listeners.' It is quite possible that Pichon's stepfather, Pierre Janet, was also invited. However, it is known that Janet was in Switzerland at that time, since the University of Geneva awarded him an honorary doctorate ès-sciences psychologiques on the occasion of his 75th birthday, which he celebrated that day. This award was presented to him at the solemn commemorative session of the 375th anniversary of the University of Geneva on 4 June 1934.

16 On the one hand, Jacques Lacan (1901-1981) acknowledges, during his first seminar, that the interest of the Jungian investigation de par 'the parallels it establishes between what some mental or religious askesis produces and what a schizophrenic produces' (Lacan 1991: 116), which is precisely what the lecturer did indeed attempt to show that evening of June 1934, stating in particular the "psychic orientation that the images of yoga seek to obtain is in perfect analogy with the goal to which his patients tend by performing drawings of the same kind' (Jung 1934). On the other hand, the analogy that the Parisian psychoanalyst would later draw up between Jung and Jakob Boehme can be interpreted as a reminiscence, or at least an allusion to the part of his presentation devoted to the so-called mandala named the 'philosophical eye' or the 'inverted eye' of the German theosophist (Lacan 1991: 496). Jacques Lacan's presence at the meeting of the Swiss Association of Psychiatry, in Prangins, October 7-8, 1933 at which Jung gave a short lecture 'On Hallucination' (1933, CW 18: §1113-1114) is proven, as evidenced by the review he devoted to that event (Lacan, 1933). But the 
would have come to meet the author with whom his publishing house, the Éditions Montaigne, had just concluded an agreement, as well as a person in charge of the Librairie Stock, in particular Maurice Delamain. Other well-known or emerging writers were also present: Edmond Jaloux; Jean Cassou who wished to publish a French translation of Wandlungen und Symbole der Libido; and the young Franco-American writer Julien Green, who wrote a relatively brief but lively account of the evening in his Diary.

It is not possible to determine the venue of the lecture. However, Julien Green (1900-1998) spoke about the Boulevard Malesherbes in the $17^{\text {th }}$ arrondissement of Paris, not far from the Parc Monceau and the Cernuschi Museum of Asian Arts (Green 1990: 1526). ${ }^{17} \mathrm{He}$ describes the place as 'a long room of the period of Henri II', decorated with a 'lofty fireplace of the baronial type'. Green adds, 'a hideous pane of stained glass concealed an electric light bulb which cast a sinister light' on the audience, according to the young writing, essentially composed of Germans. No doubt Green did not distinguish the Germans from the Swiss-Germans, nor the French-speaking Germans. The lecturer is 'a tall old man, with sanguine complexion and a white moustache. He was in evening dress, and with a calm, quiet delivery he told us the most astonishing things' (Green 1939: 172). Jung is in his 59th year. From October, he delivers a series of courses on 'Modern psychology' at the Eidgenössische Technische Hochschule in Zurich (Swiss Federal Institute for Technology), which attracts a large audience. Rumours also began to spread, accusing him of anti-Semitism and sympathy for the National Socialist ideology because of his involvement in the International General Medical Society of Psychotherapy, and following a polemical article published in the Zentralblatt für Psychotherapie. However, it seems that at this time only a small number of French people have begun to hear about it.

supposed meeting in 1954 between C. G. Jung and Jacques Lacan, organised by Jung's disciple Roland Cahen, seems more than doubtful. Other than Lacan's assertion that he would take from 'Jung's mouth' the word that Freud before their arrival in New York would have told him that he would bring them the 'plague', nothing confirms it. Roland Cahen's account, collected by Elisabeth Roudinesco for his biography of Jacques Lacan, and presented as the only proof of this meeting, seems to us to be subject to caution (Roudinesco 1993: 348). Roland Cahen, who admits that he did not attend the meeting, seems above all to have wanted to play a beautiful role by appearing alongside his two major figures in 20th century psychiatry.

17 Green says during this interview: 'I remember attending a lecture of Jung with Edmond Jaloux and Jean Cassou in June 1934. It was a beautiful evening, boulevard Malesherbes, a deserted and silent boulevard Malesherbes. The lecture was very interesting. Pr. Jung had shown that there was a connection between magic drawings of India and Tibet, known as "mandalas", and drawings of children or mentally ill'. 
This talk was the resumption of a lecture given on $1^{\text {st }}$ February 1932 at a meeting of the Naturforschende Gesellschaft (Society of Natural Sciences) at the Swiss Federal Institute for Technology, and at the Zurich Club on $5^{\text {th }}$ March of the same year, of which only a summary was published (Jung, 1932a). ${ }^{18}$ It was translated into French by Marthe Schmid-Guisan, and corrected by Jung as shown in the original typescript (1934). No doubt he had thought of adapting it to his audience, as he explained previously in an interview to Jean Bruneton:

In Germany, the audience is always attentive; they understand me no matter how I speak. In the United States, I always have to be active; there, they want a live speaker! But in Frenchspeaking countries, if the beginning is not perfect, if the form is deficient - nobody listens to me! (Bruneton 1933: 687-688).

In this lecture, Jung retraces the genesis of the notion of the unconscious in psychology. He then goes on to elaborate his concept of an unconscious whose contents are characterised by a strong autonomy, and which would come from a layer of the unconscious psyche 'existing in all men and being everywhere identical in itself', called the collective unconscious. Explaining that he encourages his analysands to sketch their inner experiences, he presents a series of drawings to his audience that were done during his patients' treatment. He compares them to certain elements in mandalas from oriental art of the medieval and Renaissance periods, notably through an evocation of the German mystic and theologian Jakob Böhme. Julien Green summed it up fairly faithfully:

According to him, in the depths of our unconscious selves we all carry certain ideas which are a heritage from a distant past common to every race of humanity. Some patients of his whom he asked to make drawings have unconsciously reproduced symbolic signs of extreme antiquity, known only to Orientalists; for example, the mandalas, or magic circles adorned with cross and serpents. His meaning was made clear

18 In a letter to Wolfgang Kranefeldt, Emma Jung wrote: 'C. G. gave a very interesting lecture on 'The Hypothesis of the Collective Unconscious' at the Naturforschenden Gesellschaft on Saturday and also in the Club, with a lot of comparative pictorial material, which was certainly very puzzling for many of these "naturalists", but was welcomed by some with great interest and enthusiasm.' (Emma Jung to Wolfgang Kranefeldt, 3 March 1932, Zentralbibliothek Zurich). 
by the use of lantern-slides. Certain Tibetan or Hindu drawings have their counterpart in drawings of children of seven to twelve years of age. (The two serpents with one gigantic eye, rising from the surface of the water. The cross enclosed within a circle - I thought of Atlantis) (Green 1939: 172-173).

One of the drawings particularly struck his imagination, as he alluded to it several times in his diary. In the days that followed, Green wrote that he recalled a Tibetan image 'of an infinite complexity, the contemplation of which brings on death'. He recalled this evening again in January 1948, remembering the lecture 'on the drawings of madmen, many of which bore traces of thousands of years of memory: an illiterate person reproduced, for example, a picture of an extreme complexity which had no equivalent except in Tibetan art' (Green 1975: 321). He acknowledged that he was inspired by 'this theory of the memory of humanity, a great common source from which we draw constantly' when he wrote Varouna (1940) (translated under the title Then Shall the Dust Return), a novel whose action extends over a thousand years, in which he assumes that 'two beings, spiritually united by an unconquerable attraction, meet from century to century, recognise and love one another' (Green 1941: IX). ${ }^{19}$

It is not known whether this lecture was followed by a debate with the audience. However, Julien Green reports on a rather unpleasant episode at the end of the talk: 'The lecturer, on being asked whether he would be returning to Paris, shook his head with a fierce smile. No!' (Green 1939: 173, translation modified). No doubt Jung was sincere when he told Jean Bruneton that he maintained 'a very good memory' of his Parisian stay (Jung to Jean Bruneton, 5 June 1934). But this lecture, which was never published, was indeed his last public talk in René Descartes's country.

19 Julien Green notes in his diary that he discussed the idea of the collective unconscious after the conference with Jean Cassou and Edmond Jaloux after Jung's lecture: 'All three of us left together to gossip until 1 p.m. in a cafe on the place Pereire. They believe that constants exist in the human brain that would partly explain these strange drawings. Certain ideas, certain emotions are always expressed in the same way. They made no attempt, however, to explain by any reasoned arguments certain coincidences which are almost incomprehensible. So far as I myself am concerned, I wonder whether those mysterious signs may not be an unconscious memory of some antediluvian writing. There are so many things we inherit from our parents and from our great-grand-parents. Why should not this inheritance come down to us from a very remote period, going back to the first beginnings of humanity? We are crammed full of memories'. 


\section{EPILOGUE}

C. G. Jung must have concluded that France, with its powerful reservations about psychoanalysis in the pre-war period, was one of the most reluctant countries in Western Europe to accept his psychology. His main priorities being, on the one hand, the conquest of Germany, then largely in support of Freud's and Adler's theories (which remained his main ambition in Europe, even to the point of compromising himself with personalities close to the Nazi power), and on the other hand, the Anglo-American world, where he was delighted to find his largest audience, even receiving honours from the prestigious Harvard University, which awarded him (and Pierre Janet) an honorary doctorate in September 1936 (McGuire, 1995).

Although he was invited to join the XIIth International Congress of Psychology of 1938 in Paris-under Janet's presidency-Jung refused, on the pretext of having other commitments, intimating that such a perspective in no way tempted him (Jung to Jean Bruneton, 7 May 1937, ETH Zurich). Without making any formal commitment, he also seems to have accepted in principle to give a new lecture for the benefit of the Gros Caillou in 1939. But he asked the Parisians to remain patient, since his schedule did not allow him to prepare an 'appropriate' lecture (Marie-Jeanne Schmid to Jean Bruneton, 6 March 1939, ETH Zurich). World War II and his health problems finally made it impossible.

In the late 1940s, Jung believed for a moment that he could make a breakthrough on the French book-market - one of the most important in Europe-following the success of L'Homme à la découverte de son âme. At least that is what a part of his correspondence with his publisher Rascher shows (Bishop 1998). And this thanks to his follower Roland Cahen, more concerned to adapt his work to the so-called 'clarity' of the French mind than to translate it rigorously. However Jung lost his 'illusions' in the fifties, as he confided in a letter to Károly Kerényi (Jung to Kerényi, 12 July 1954, ETH Zurich), probably noting the commercial failure of the subsequent translations, including La guérison psychologique (1953), an anthology of his texts with a more specific psychotherapeutic scope.

Jung was to wait until the late 1950s for a professor from the Sorbonne, the early modernist historian Alphonse Dupront (19051990), to suggest that Jung be invited to Paris to organise a colloquium in his honour (Dupront to Jung, 29 November 1957, ETH Zurich). More than twenty years after he had refused to speak in the 'temple' of the 'goddess Reason', a Sorbonne professor had come to respect him. Jung 
preferred to give it up because of his advanced age (Jung to Dupront, 7 December 1957, ETH Zurich). A restricted symposium in Switzerland with the orientalist Henry Corbin and the support of the French Embassy in Bern was considered, but the project never came into being. Two years before, he made the observation during an interview, not without a touch of bitterness: 'The Anglo-Saxons understand me better than the French. The French are either Cartesians, or Catholics' (Schabad 1955: 271). Finally, shortly before he passed away, Jung regretted in a letter to one of his pupils that he remained 'almost totally unknown to the French readership' (Jung to Suzanne Percheron, 21 March 1961, SFPA).

Temps, Mondes, Sociétés, TEMOS CNRS FRE 2015, Université Bretagne-Loire, Le Mans Université, Avenue Olivier Messiaen, 72085 LE MANS CEDEX 9, France florent.serina@gmail.com

\section{REFERENCES}

de Angulo, Ximena. 1977 [1952]. 'Comments on a doctoral thesis'. In William McGuire and R. F. C. Hull (eds.), C. G. Jung speaking. Princeton: Princeton University Press: 205-218.

Arnaud, Patrice. 2000. 'Gaston Bruneton et l'encadrement des travailleurs françaisen Allemagne (1942-1945)'. Vingtième Siècle. Revue d'histoire 67 (67): 95-118.

Bishop, Paul. 1998. 'On the history of analytical psychology: C. G. Jung and the Rascher Verlag: Part 1'. Seminar 34 (3): 256-279.

Centre culturel international de Cerisy-la-Salle. 1976. Entretiens autour de Gabriel Marcel. Neuchâtel: Éditions de la Baconnière.

Bruneton, Jean. 1933. 'Jung: l'homme, sa vie, son caractère'. Revue d'Allemagne VII: 673-689.

Bruneton, Jean. Letter dated 25 December 1933 to C. G. Jung. C. G. Jung Papers Collection, ETH-Bibliothek, ETH Zurich University Archives. Hs 1056: 2991.

Cabot Reid, Catharine and Cabot Reid, Jane. 2001. Jung, My Mother and I. The Analytic Diaries of Catharine Rush Cabot. Einseldeln: Daimon.

Cahen, Roland. 1944. 'Préface'. In Jung, C. G. L'Homme à la découverte 
de son âme. Genève, Annemasse: Éditions du Mont-Blanc.

Dupront, Alphonse. Letter dated 29 November 1957 to C. G. Jung. C. G. Jung Papers Collection, ETH-Bibliothek, ETH Zurich University Archives. Hs 1056: 23895.

Frémont, Marguerite. 1994. La Vie du docteur Allendy 1889-1942. Castelnau-le-Lez: Climats.

Fröbe-Kapteyn, Olga. Letter dated 28 October 1935 to Lucien Lévy-Bruhl. Institut Mémoires de l'édition contemporaine (IMEC). Lucien Lévy-Bruhl papers. LVB 4.324.

1942. 'Eranos. A survey of its history since 1933, of the facts connected with it, a. the Tagungen $b$. the Archive. The conclusion I have arrived at, my psychological realizations concerning it, its differences from other congress centers, and its chief problem'. Ascona: Fondazione Eranos.

Freud, Sigmund. Letter dated 20 February 1935 to Lucien Lévy-Bruhl. Institut Mémoires de l'édition contemporaine (IMEC), Abbaye d'Ardenne. Lucien Lévy-Bruhl papers. LVB 9.

Green, Julien. 1939. Personal Record 1928-1939. New York: Harper \& Brothers Publishers.

- 1941. Then Shall the Dust Return, translated by James Withall. New York, London: Harper.

1990 [1982]. 'La passion du bonheur. Entretien avec Sophie Lannes'. CEuvres complètes VI, Paris: Gallimard.

Halévy, Daniel. 1920. 'L'Histoire littéraire. Période contemporaine (1870-1920)'. La Minerve française 25: 774-775.

1932a. 'Les propos de Zurich.' Les Nouvelles Littéraires 18 (June): 1-2.

—. 1932b. Courrier de Paris. Paris: Éditions du Cavalier.

— 1933. Courrier d'Europe. Paris: Éditions Bernard Grasset.

—. 1934. 'Un médecin d'âmes'. 1934. Le Magazine d'aujourd'hui 42 (July) 23, 3.

. Letter dated 23 May 1934 to C. G. Jung. C. G. Jung Papers Collection, ETH-Bibliothek, ETH Zurich University Archives. Hs 1056: 2029. 
Jenkins, Brian \& Chris Millington. 2015. France and Fascism: February 1934 and the Dynamics of Political Crisis. London, New York: Routledge.

Jouve, Pierre-Jean. Letter dated 8 June 1945 to C. G. Jung. C. G. Jung Papers Collection, ETH-Bibliothek, ETH Zurich University Archives. Hs 1056: 11448.

Jung, C. G. [1928]. 'The Swiss Line in the European Spectrum'. Collected Works of C. G. Jung. Vol. 10: $\S \S ~ 903-924$.

- 1932a. Die Hypothese des kollektiven Unbewussten. GW 18: $\S 1223-1225$.

- Letter dated 18 July 1932 to Jean Bruneton. C. G. Jung Papers Collection, ETH-Bibliothek, ETH Zurich University Archives. Hs 1056: 1543.

1934. 'L'hypothèse de l'inconscient collectif.' Translated by M. Schmid-Guisan. C. G. Jung Papers Collection. ETH-Bibliothek. ETH Zurich University Archives. Hs 1055: 675.

- [1935]. The Tavistock Lectures. CW 18: §§1-415.

—. Letter dated 21 February 1935 to Lucien Lévy-Bruhl. Institut Mémoires de l'édition contemporaine (IMEC), Abbaye d'Ardenne, Lucien Lévy-Bruhl papers, LVB 5.38 . - Letter dated 12 March 1935 to Jolande Jacobi. C. G. Jung Papers Collection, ETH-Bibliothek, ETH Zurich University Archives. Hs 1056: 3924.

—. Letter dated 31 July 1935 to Lucien Lévy-Bruhl. C. G. Jung Papers Collection, ETH-Bibliothek, ETH Zurich University Archives. Hs 1056: 3989.

- Letter dated 1 August 1936 to Gustav Richard Heyer. C. G. Jung Papers Collection, ETH-Bibliothek, ETH Zurich University Archives. Hs 1056: 5017.

. Letter dated 7 May 1937 to Jean Bruneton. C. G. Jung Papers Collection, ETH-Bibliothek, ETH Zurich University Archives. Hs 1056: 6020. . [1944-1952]. Psychology and Alchemy. Collected Works of C. G. Jung, vol. 12.

—. Letter dated 18 June 1945 to Jean Desplanque. 
C. G. Jung Papers Collection, ETH-Bibliothek, ETH Zurich University Archives. Hs 1056: 11815.

Letter dated 12 July 1954 to Károly Kerényi. C. G. Jung Papers Collection, ETH-Bibliothek, ETH Zurich University Archives. Hs: 20719.

- Letter dated 7 December 1957 to Alphonse Dupront. C. G. Jung Papers Collection, ETH-Bibliothek, ETH Zurich University Archives. Hs 1056: 24601.

- 1961. Letter dated 21 March to Suzanne Percheron Société Française de Psychologie Analytique (SFPA), Paris.

—. 1973. Letters I, 1906-1950, edited by Gerhard Adler in collaboration with Aniela Jaffé, translated by R. F. C. Hull, Bollingen Series XCV. Princeton: Princeton University Press. 1984. Dreams Analysis. Notes of the Seminar given in 1928-1930, volume 1. Edited by William McGuire. London: Routledge Kegan Paul.

1989. Nietzsche's Zarathustra. Notes of the Seminar Given in 1934-1939, volume 1. Edited by James L. Jarrett, London: Routledge.

. 2012. Introduction to Jungian Psychology. Notes of the Seminar on Analytical Psychology Given in 1925. Original edition edited by William McGuire. Translated by R.F.C. Hull with a new introduction and updates by Sonu Shamdasani. Princeton: Princeton University Press.

Jung, Carl Gustav / Jaffé, Aniela. [1962]. Memories, Dreams, Reflections, tr. Clara and Richard Winston. New York:Vintage Books, 1989.

Jung, Emma. Letter dated 3 March 1932 to Wolfgang Kranefeldt. Zentralbibliothek, Zurich, Ms Z VII 3952.

—. 2004 [1957]. 'On the nature of the animus'. translated by C. F. Baynes, Animus and Anima. Putnam: Spring Publications.

Keyserling, Hermann Graf von. 1928. Europe: 'Das Spektrum Europas'. London: Cape.

Lacan, Jacques. 1933. ' $84^{\text {e }}$ Assemblée de la Société Suisse de Psychiatrie à Prangins les 7-8 octobre 1933'. L'Encéphale 8: 686-695.

. 1991. Freud's Papers on Technique 1953-1954, edited by Jacques-Alain Miller, translated with notes by John Forrester. 
New York, London: W. W. Norton \& Company.

Laurent, Sébastien. 2001. Daniel Halévy. Du libéralisme au traditionalisme. Paris: Éditions Grasset \& Flasquelle.

Lévy-Bruhl, Lucien. 1935a. 'Remarques sur l'initiation des medicine-men'. Psychologischen Club (ed.), Die Kulturelle Bedeutung der komplexen Psychologie. Berlin: Julius Springer.

—. 1935b. 'Agendas'. Institut Mémoires de l'édition contemporaine (IMEC). Abbaye d'Ardenne: Lucien Lévy-Bruhl papers, LVB 1.5.

—. Letter dated 26 April 1935 to Eduard von der Heydt. Ascona: Fondazione Eranos.

—. 1936-1937. 'L'expérience mystique chez les primitifs'. Psychologischer Club Zürich Jahresbericht: 29-30; revised and expanded under the same title, 1938. Nouvelle Revue française 294: 370-391.

Mazauric, Lucie. 1972. Avec André Chamson. Paris: Plon.

McGuire, William (ed.). 1974. The Freud/ Jung Letters, translated by Ralph Manheim and R. F. C. Hull. Princeton: Princeton University Press, Bollingen Series XCIV.

McGuire, William. 1995. 'Firm Affinities'. Journal of Analytical Psychology 40: 301-326.

Ocampo, Victoria. 2007. Drieu. Suivi de lettres inédites de Pierre Drieu la Rochelle à Victoria Ocampo. Paris: Bartillat.

Pellissier, Pierre. 2000. 6 février 1934. La République en flammes. Paris: Perrin.

Pichon, Édouard. 1934. 'La Polarisation Masculin-Féminin'. L'Évolution psychiatrique III: 59-96.

Pietikäinen, Petteri. 1998. 'National typologies, races and mentalities in C. G. Jung's Psychology'. History of European Ideas 24 (6): 359-373.

Roudinesco, Elisabeth. 1993. Jacques Lacan. Esquisse d'une vie, histoire d'un système de pensée. Paris: Fayard.

Schabad, Michael. 1977 [1955]. 'An Eightieth Birthday Interview'. In William McGuire and R. F. C. Hull (eds.) C. G. Jung speaking. Princeton: Princeton University Press: 268-272.

Schmid, Marie-Jeanne. Letter dated 6 March 1939 to Elisabeth 
von Sury. C. G. Jung Papers Collection. ETH-Bibliothek. ETH Zurich University Archives. Hs 1056: 8723.

Seillière, Ernest. 1928. Le Néoromantisme en Allemagne I. Psychanalyse freudienne ou psychologie impérialiste? Paris: Félix Alcan. 1938. 'Du recours à l'inconscient'. Journal des débats politiques et littéraires October $1^{\text {st. }} 3$.

Swiggers, Pierre. 1987. 'À l'ombre de la clarté française'. Langue française 75 (75): 5 - 21.

Sygne. 1932. 'M. Daniel Halévy’. Le Charivari October 15.

\begin{abstract}
AKNOWLEDGMENT
I am grateful to the Stiftung der Werke von C. G. Jung and the Paul \& Peter Fritz AG Literary Agency for permission to quote brief extracts from unpublished letters (C) 2007 Stiftung der Werke von C. G. Jung, Zürich). I am also indebted to the Fondazione Eranos, Ascona, for granting the permission to consult the letter from Lucien LévyBruhl (probably) addressed to the baron Eduard von der Heydt, and the unpublished paper of Olga Fröbe-Kapteyn. I would also like to express my sincere appreciation to Deirdre Westgate for her role as editorial consultant; her contributions to the translation of this revised and enlarged chapter of my thesis have greatly improved it.
\end{abstract}

